\title{
Birds Behaving Badly: The Regulation of Seagulls and the Construction of Public Space
}

\begin{abstract}
Sarah Trotter*
Abstract: This article is about the socio-legal construction of one of the least-loved birds in the UK: the 'seagull'. In particular, it is about how the gull has been brought within the realm of the 'anti-social', in a context in which urban-nesting gulls (of which there are many in the UK) are cast as causing a great deal of public nuisance, ranging from noise, aggression, and mess, to attacks, injuries, and stress. The article examines the measures that have been adopted by local authorities to regulate the gull population - and to regulate people, in the name of regulating gulls - and it shows how a construction of the 'seagull' underpins - and justifies - this regulatory framework. It argues that the story of the regulation of seagulls in the UK is also a story about the construction of public space, to the point that the measures adopted here challenge the idea of public space.
\end{abstract}

"We and the gulls are co-babitants of the same world, uncomfortably recognizing each other, thriving in the same way, failing in the same way, behaving badly in the same way." (Adam Nicolson, The Seabird's Cry) ${ }^{1}$

\section{INTRODUCTION}

Seagulls rarely get a good press in the UK. Every year, when it comes to the months of their breeding season (between April and late July), the newspapers fill with tales of their wrongdoing. At best, they are deemed noisy, aggressive, and messy; at worst, they are portrayed as being

*Law Department, London School of Economics and Political Science, Houghton Street, London, WC2A 2 AE. Email address: s.trotter@,Lse.ac.uk.

Acknowledgements: I would like to thank the local authorities that were contacted as part of this research for responding so willingly to the freedom of information requests on which this article is based. I am also very grateful to the participants of the 'Dissents and Dispositions' conference of the Law, Literature and Humanities Association of Australasia for their engagement with the first version of this paper in December 2017 and to Kai Möller, Damian Chalmers, Michael Blackwell, and the anonymous reviewers for their valuable comments on subsequent versions.

${ }^{1}$ A. Nicolson, The Seabird's Cry: The Lives and Loves of Puffins, Gannets and Other Ocean Voyagers (2017), 121. 
'attackers', 'invaders', 'terrorisers', 'divebombers', ${ }^{4}$ and 'killers'. ${ }^{6}$ Seaside towns, in particular, are cast as being dangerous places to be, owing to the possibility of being 'dive-bombed' and injured by a gull. ${ }^{7}$ In fact, if we took all the news reports about gulls together, and drew up a picture of seagulls in the UK based on these alone, we would probably come up with something similar to Alfred Hitchcock's adaptation of Daphne du Maurier's The Birds; and indeed the parallels with Hitchcock's film are drawn all too frequently in the press reporting on urban gulls. ${ }^{8}$

In July 2015, in the midst of an ever-deepening representation of seagulls in these terms, the scale of the gull-related problems being depicted led the then Prime Minister, David Cameron, to call for a "big conversation" about the seagull 'problem';' and in February 2017, it was debated by Members of Parliament (MPs) in the House of Commons. ${ }^{10}$ This was not the first time for seagulls to make it into Westminster; ${ }^{11}$ but the February debate was the most sustained that there had ever been, and it reflected an increasing degree of attention to a subject that has bothered local authorities for years and has led to them expending in large numbers (and particularly in coastal areas) a significant amount of time and resources on trying to come to grips with gull-related problems. ${ }^{12}$ Authorities are limited in this quest - as are members of the public more generally by the legal protection that gulls derive from their status as protected birds under the Wildlife and Countryside Act 1981 and the Wildlife (Northern Ireland) Order 1985. Only exceptionally can licences be obtained to take measures against gulls that would otherwise be illegal (that is, measures

${ }^{2}$ E.g., The Telegraph 'Attack of the birds: rising number of people injured by seagulls on Britain's coast' (18 August 2017) < http://www.telegraph.co.uk/news/2017/08/18/attack-birds-rising-numbers-injured-seagulls-britainsbeaches $/>$.

${ }^{3}$ E.g., The Daily Mail, 'Meet your new neighbours: The marauding seagulls invading Britain's towns' (9 January 2009) < http://www.dailymail.co.uk/news/article-1110974/Meet-new-neighbours-The-marauding-seagulls-invadingBritains-towns.html>.

4 E.g., The Independent, 'Far from the sea, urban seagulls terrorise skies' (27 August 2010) $<$ http://www.independent.co.uk/environment/nature/far-from-the-sea-urban-seagulls-terrorise-skies2064013.html>.

${ }^{5}$ E.g., The Telegraph, 'Divebombing seagulls trap ‘terrified' children inside during hottest day of year' (23 June 2017) <http://www.telegraph.co.uk/news/2017/06/23/divebombing-seagulls-trap-terrified-children-inside-hottest/>.

6 E.g., The Times, 'Killer seagulls flip pet tortoise to dine on it "like a crab" (17 July 2015) $<$ https://www.thetimes.co.uk/article/killer-seagulls-flip-pet-tortoise-to-dine-on-it-like-a-crab-5zzh6l6xv6q >.

${ }^{7}$ E.g., The Independent, 'What happens when seagulls attack? "It's a war zone, we are even seeing people with mouth injuries"” (9 August 2017) < https://www.independent.co.uk/news/long reads/what-happens-when-seagulls-attackits-a-war-zone-people-are-even-getting-injuries-in-their-mouths-a7883676.html>.

8 E.g., The Guardian, 'Woman injured in "Hitchcock-style" bird attack' (10 July 2008) $<$ https://www.theguardian.com/uk/2008/jul/10/1>.

9 BBC, 'Gull attacks: David Cameron wants "big conversation"” (17 July 2015) < http://www.bbc.co.uk/news/ukengland-cornwall-33573807>.

10 'Seagulls', 621, H.C. Debs., cols.73WH-97WH (7 February 2017).

11 E.g., 'Controlling Urban Seagulls', 491, H.C. Debs., cols.469-474 (23 April 2009); 'Seagulls (Gloucester)', 505, H.C. Debs., cols.237WH-243WH (9 February 2010); 'Seagulls (Coastal Towns)', 534, H.C. Debs., cols. 142WH-148WH (26 October 2011).

12 BBC, 'Council spending on tackling pigeons and gulls doubles' (17 February 2017) $<$ http://www.bbc.co.uk/news/uk-england-38893142>. 
to destroy their nests and eggs), and therefore gulls in the UK are, for the most part, happily shielded from the reality of the support of $44 \%$ of the population for a 'seagull cull' - a figure which rises to $50 \%$ in rural areas. ${ }^{13}$ The efforts of local authorities have tended to focus instead on control measures, such as bird-proofing measures on buildings (bird-netting or roof spikes, for example) and public information campaigns (such as 'do not feed the birds' signs in the streets).

Critics say, however, that the measures available to deal with the problems caused by seagulls are insufficient. It is in this context, in recent years, that attention has shifted to the use of anti-social behaviour measures that are targeted at individuals who like feeding the birds. In April 2017, for example, and as was widely reported (and ridiculed) in the media, East Devon District Council introduced a Public Spaces Protection Order (PSPO) that enables it to issue fixed penalties of $£ 80$ to anyone who 'at any time...provides or deposits food for consumption by seagulls on the promenades, beaches and/or foreshore within the administrative area of East Devon District Council unless he has reasonable excuse for doing so.' ${ }^{4}$ "What, like fish?" quipped Sara Pascoe when the topic of "aiding and abetting gulls" in this way (Ian Hislop's phrasing) subsequently came up for discussion on the BBC comedy news quiz show Have I Got News for You in May $2017 .{ }^{15}$ But joke as we may, East Devon District Council is not alone in this move, and, as we will soon see, other local councils are following suit in the creation of PSPOs to regulate bird-feeding.

This article, then, is about the socio-legal construction of the 'seagull' in the UK and about the corresponding local regulation of the seagull 'problem'. It shows how a particular construction of the 'seagull' underpins - and justifies - the regulatory approaches adopted to gulls; and it argues, more broadly, that the story of the regulation of seagulls in the UK is also a story about the construction of public space and about how we understand public space. The first part of the article looks at how the gull has been envisaged in law and in the popular imagination from the mid-nineteenth century until the present day. In particular, I trace the shift towards the negative portrayal that culminates in the view, expressed in the House of Commons in February 2017, that 'we' are at 'war' with urban gulls. In the second part, I consider how, in the light of this, gulls are in fact regulated, drawing on data that I obtained from local authorities across the UK. There are two modes of regulating the gull 'problem': via measures that are targeted at birds 'behaving badly' or via measures that are targeted at humans 'behaving badly'. The third part of the article examines what exactly is meant by 'bad behaviour' in this context. Finally, in the fourth part, I analyse the

\footnotetext{
${ }^{13}$ See < https://yougov.co.uk/news/2015/08/05/gull-cull/>.

14 East Devon District Council, Seashores and Promenades Public Spaces Protection Order 2017 $<$ http://eastdevon.gov.uk/media/2109378/final-seashore-and-promenade-order-with-maps.pdf $>$.

15 BBC, Have I Got News for You (Series 53, Episode 3), 5 May 2017, at 17:11-19:56.
} 
vision of public space that emerges through this study into the regulation of seagulls. I suggest, in particular, that the regulatory measures adopted here challenge the very idea of public space.

\section{'SEAGULLS' AND THE LAW: FROM WILDLIFE PROTECTION TO “GULL WARS”}

It is probably a little bit puzzling to be reading an article all about 'seagulls' when no such bird as the 'seagull' actually exists. The term is simply a popular way of referring to the birds that comprise the gull family (which are, in turn, of the Laridae family of seabirds); and so that is the way in which I will use it in this article too, in order to convey and analyse both the way in which the 'seagull' is imagined in the UK and the construction of the 'seagull problem'. In fact, as we will soon see, it is a large part of the nature of the construction of the 'seagull problem' that when we use the term 'seagull' to denote a particular bird, or speak in general terms about 'seagulls', we are not being very specific. But before we come on to the detail of the 'seagull problem', it is worth briefly outlining the different species that the term 'seagull' alludes to, and their distribution across the UK.

There are seven species of gull that breed in the UK: the common gull (49,000 breeding pairs), the black-headed gull (140,000 breeding pairs), the black-legged kittiwake (380,000 breeding pairs), the great black-backed gull (17,000 breeding pairs), the lesser black-backed gull $(110,000$ breeding pairs), the herring gull (140,000 breeding pairs), and the Mediterranean gull (600-630 breeding pairs). ${ }^{16}$ All seven species are deemed a conservation priority in the latest Birds of Conservation Concern assessment, being either listed red-listed (the highest level of conservation concern: the black-legged kittiwake and the herring gull) or amber-listed (the middle level of conservation concern: the black-headed gull, the common gull, the great black-backed gull, the lesser black-backed gull, and the Mediterranean gull). ${ }^{17}$ Each species differs in its habits and in its distribution; but broadly speaking, whereas black-headed gulls, lesser black-backed gulls, and herring gulls are widely distributed (with the black-headed gull, in particular, breeding in similar numbers both inland and on the coast), the other species are typically more confined to particular areas. ${ }^{18}$ Thus the black-legged kittiwake is mostly to be found in large colonies along the North Sea coast, and especially around Orkney and Shetland; the Mediterranean gull is mostly to be found along the south and south-east coasts of England; the common gull is almost entirely confined to

$16<$ https://www.rspb.org.uk/birds-and-wildlife/bird-and-wildlife-guides/browse-bird-families/gulls.aspx $>$.

${ }^{17} \mathrm{M}$. Eaton et al., 'Birds of Conservation Concern 4: the population status of birds in the UK, Channel Islands and Isle of Man' (2015) 108 British Birds, 708-746. See further Seabird Population Trends and Causes of Change: 1986-2015 Report (2016) $<$ http://incc.defra.gov.uk/page-3201>.

${ }^{18}$ See further $<$ http://incc.defra.gov.uk/page-3176> . 
Scotland and Northern Ireland; and the great black-backed gull is mostly to be found along the Atlantic Sea coast - particularly in the Outer and Inner Hebrides - and also around Orkney and Shetland. ${ }^{19}$

In the UK, the law first concerned itself with gulls with the Sea Birds Preservation Act of 1869, which was passed in response to a decline in the seabird population (one of the contributing factors to which was the popularity of seabird hunting). The Act provided protection for seabirds (including gulls) during the breeding season, which was defined as 1 April - 1 August. It made only one exception to the general scope of its application, and this was for St Kilda ${ }^{20}-$ a remote archipelago lying 40 miles north-west of North Uist, in the Outer Hebrides, where people were "entirely dependent on sea-birds for their subsistence". ${ }^{21}$ The impetus for the 1869 Act came primarily from the Yorkshire Association for the Protection of Sea Birds, which was founded for this purpose. ${ }^{22}$ The Act was moved by Christopher Sykes, the MP for the East Riding of Yorkshire, who expressed the interests of "three very important classes of his constituents" in the preservation of the seabird population: the farmers, the merchant sailors, and the deep-sea fishers. ${ }^{23}$ The farmers "were accustomed to see flocks of sea birds following at the heels of the ploughboy and from the newly turned-up earth picking up worms and grubs" (and one influential farmer, Sykes reported, had not seen "a single bird on his farm" the preceding summer). ${ }^{24}$ For merchant sailors, "in foggy weather those birds, by their cry, afforded warning of the proximity of a rocky shore, when neither a beacon-light could be seen nor a signal-gun heard" (and, Sykes noted, "with the decrease of those birds the number of vessels which had gone ashore at Flamborough Head had steadily increased"). ${ }^{25}$ Finally, the seabirds assisted the deep-sea fishers, "because, by hovering over the shoals of fish, those birds pointed out the places where the fisherman should cast his net". ${ }^{26}$

The concern was, then, that the continued decline in the seabird population would eventually result in the extermination of these birds, and therefore in the loss of all the assistance that they offered. There was also much concern about the number of gulls being destroyed so that their plumage could be used in women's hats, which was a popular trend in the 1860 s. $^{27}$ It was this

\footnotetext{
19 id.

20 Sea Birds Preservation Act 1869, s. 8.

21 P. Barclay-Smith, 'The British Contribution to Bird Protection' (1959) 101 IBIS: The International Journal of Avian Science 115, at 116.

22 Barclay-Smith, id., p.115.

23194 Parl. Debs., col. 405 (26 February 1869).

24 id.

$25 \mathrm{id}$.

26 id.

${ }^{27}$ D. E. Allen, The Naturalist in Britain: A Social History (1994, $2^{\text {nd }}$ edn.), 177-178.
} 
in fact that also led to the establishment of the Plumage League by Emily Williamson in 1889, which demanded from its "lady-members" that they "refrain from wearing the feathers of any bird not killed for the purposes of food, the ostrich only excepted". ${ }^{28}$ The Plumage League became the Royal Society for the Protection of Birds (RPSB) in 1904; and the RSPB has since then been the most important body for the protection of birds in the UK.

Fast forward to today, and gulls (and their nests and eggs) are legally protected, like all wild birds, under the Wildlife and Countryside Act 1981 and, in Northern Ireland, under the Wildlife (Northern Ireland) Order 1985. The 1981 Act prohibits the killing, injuring, or taking of any wild bird; the taking, damaging or destroying of the nest of any wild bird; and the taking or destroying of an egg of any wild bird. ${ }^{29}$ There is a slim exception to this protection. In exceptional circumstances, pertaining to public health and safety, licences can be obtained (from authorities in England, Wales, Scotland, and Northern Ireland) to take measures against gulls that would otherwise be illegal (such as removing or destroying the nests and eggs of herring gulls). But the threshold for obtaining such licences is quite high, and other options for managing the alleged bird problem must have been tried first. If we look at gulls through the lens of formal law alone, then, what we see is the construction of the gull as a subject of protection, an object of concern.

But over the years, another narrative has emerged and bound itself into this tale of gulls and the law in the UK. This is the narrative of the problem seagull: the urban-nesting gull. This is usually a herring gull or a lesser black-backed gull, ${ }^{30}$ but common gulls and great black-backed gulls have also been reported at urban sites since the $1980 \mathrm{~s} .{ }^{31}$ Colonies of herring gulls and lesser blackbacked gulls were the first to nest at urban locations, however, beginning in the 1940s, and by the 1970s they were flourishing in towns and cities across the UK. ${ }^{32}$ Up until the early 1970s, there was a significant increase in the overall population of these gulls on both natural and urban sites, which has been most widely attributed to the extra food availability that stemmed from post-war changes to waste management practices. ${ }^{33}$ In particular, new and larger landfill sites were built; and the Clean Air Act of 1956 - which was passed in response to the Great Smog of London of 1952 and was aimed at reducing air pollution - prohibited the burning of waste at these sites, meaning

\footnotetext{
$28<$ https://ww2.rspb.org.uk/about-the-rspb/about-us/our-history/>. The exception for ostriches was because of its not being necessary to kill them for their feathers.

${ }^{29}$ Wildlife and Countryside Act 1981, s. 1; Wildlife (Northern Ireland) Order 1985, s. 4.

$30 \mathrm{On}$ the regional variation in the abundance of each, see S. J. Raven and J. C. Coulson, 'The distribution and abundance of Larus gulls nesting on buildings in Britain and Ireland' (1997) 44 Bird Study 13, at 20-21.

31 id. pp.23-24.

32 P. Rock, 'Urban gulls: problems and solutions' (2005) British Birds 338, at 338-339.

33 id., but cf. J. C. Coulson, 'Re-evaluation of the Role of Landfills and Culling in the Historic Changes in the Herring Gull (Larus argentatus) Population in Great Britain' (2015) 38 Waterbirds 339.
} 
that it was covered with inert material at the end of the day and in the interim created a "new, enhanced feeding opportunity" for gulls. ${ }^{34}$

From the 1970s onwards, however, the trajectories of the urban colonies and the naturalsite colonies diverged. There was a general decline in the overall population of herring gulls and lesser black-backed gulls (attributed in the literature, at least in part, to the incidence of botulism ${ }^{35}$ ) that was evident in the natural-site colonies but not in the urban colonies, which continued (and still continue) to grow. ${ }^{36}$ John Coulson has suggested that in the case of herring gulls, the paradox of their continuing spread in urban areas, at the same time as the continuing decline in their overall population, can possibly be explained by the fact that in some parts of the country at least, urban herring gulls tend not to feed at landfill sites, where botulism is more likely. ${ }^{37}$ His research in northeast England found that urban herring gulls rather "fed predominantly at sea, along the shore and in fields". ${ }^{38}$

Since the 1970s, then, gulls have firmly established themselves in colonies in towns and cities across the UK. And why wouldn't they? They seem to have many good reasons for settling in urban environments: "there are no predators; disturbance is minimal; ambient temperatures in towns are c. $2-6^{\circ} \mathrm{C}$ warmer than the surrounding countryside, which permits earlier breeding; and street lighting allows gulls to feed at night as well as during the day". ${ }^{39}$

But all is not well; for according to many, urban gulls do not make good neighbours. They are deemed noisy, aggressive, and messy at best, and 'divebombers', 'attackers', 'invaders', 'terrorisers', and 'killers' at worst. ${ }^{40}$ It is in fact not possible to convey, within the confines of this article, the sheer extent and number of negative headlines about 'seagulls' that abound on an annual basis come the breeding season. We can perhaps point more clearly to the effects of this reporting. In July 2015, in the midst of a "media frenzy" about urban gulls" and following what was subsequently called in a House of Commons briefing "[a] spate of seagull attacks across the country", ${ }^{42}$ the then Prime Minister, David Cameron, told listeners of BBC Radio Cornwall that

\footnotetext{
${ }^{34}$ Rock, op. cit., n32, p.339.

${ }_{35}$ Botulism is a disease that is caused by the ingestion of a toxin produced by the bacterium Clostridium botulinum.

${ }^{36}$ Rock, op. cit., n32, p339; Coulson, op. cit., n33, p.350.

${ }^{37}$ Coulson, op. cit. n33, p.352.

38 id. p.348.

${ }^{39}$ Rock, op. cit., n32, p.340.

${ }^{40}$ See n2-8.

41 The Guardian, “Killer" seagulls top the pecking order for media frenzy" (23 July 2015) $<$ https://www.theguardian.com/environment/2015/jul/23/killer-seagulls-top-the-pecking-order-for-a-mediafrenzy $>$.

${ }^{42}$ House of Commons Library (D. Hirst and J. Baker), 'Debate Pack: Seagulls in coastal towns and cities' (2017), 2 <http://researchbriefings.files.parliament.uk/documents/CDP-2017-0044/CDP-2017-0044.pdf>.
} 
there needed to be a "big conversation" about seagulls, having read in the papers that morning about "how aggressive the seagulls are now in St Ives" and concluding that "we do have a problem". ${ }^{43}$ This request came, somewhat awkwardly, only a few weeks after his Chancellor, George Osborne, axed Government funding for a $£ 250,000$ research project into urban gulls; ${ }^{44}$ but Cameron's call nevertheless succeeded in drawing great attention to the big seagull 'problem'.

There followed, one afternoon in February 2017, a House of Commons debate on the subject. This was introduced by Oliver Colvile, the then MP for Plymouth Sutton and Devonport, who opened the debate by expressing his pleasure at having the "opportunity to talk about an issue that has plagued many people" not only in his constituency but also "throughout the UK". ${ }^{45}$ MPs went on to express a number of common concerns, such as about the effect of "increasingly aggressive seagulls" on tourism in their constituencies; ${ }^{46}$ the health and safety risk posed to people and pets; ${ }^{47}$ the general nuisance - the "noise and filth" - caused by gulls; $;^{48}$ the effect of seagulls on the quality of life of constituents; ${ }^{49}$ and the importance of "shoppers, residents and tourists [feeling] safe when they are outdoors". ${ }^{50}$ Then there were the more constituency-specific problems: in Aberdeen, the sheer size of the gull ("the Aberdeen seagull is the size of a large dog" ${ }^{\text {, } 11}$ ); in Cornwall, that these "flying rats" scavenge and steal "whenever they can", 52 in Largs, that "nothing can really be safely eaten on the shorefront without risking life and limb at the hands, or...beak, of a vicious seagull", ${ }^{53}$ in Maryport, that seagulls have in the past caused delays to postal deliveries, ${ }^{54}$ and in Berwick-upon-Tweed, that there was "a risk that people are having to take the law into their own hands to deal with these difficult and aggressive birds", meaning that "there are people wandering the streets of Berwick with firearms who really should not be doing so". ${ }^{55}$

MPs did suggest some solutions to this apparent gull problem - a problem which ranged in its specification from the notion that "seagulls are beginning to behave badly"

43 The Guardian, 'Seagull attacks: David Cameron calls for "big conversation” about issue' (18 July 2015) $<$ https://www.theguardian.com/politics/2015/jul/18/seagull-attacks-david-cameron-big-conversation>.

${ }^{44}$ The Guardian, 'Seagull menace: Osborne's funding cut for study into birds' aggression criticised' (24 July 2015)

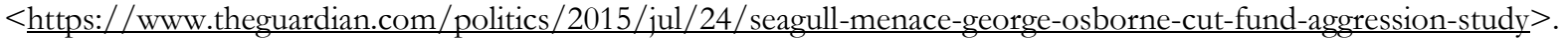

${ }^{45}$ H.C. Debs, op. cit., n10, col.73WH.

${ }^{46} \mathrm{id}$. col.73WH; see also cols.82WH-83WH, col.85WH.

47 id. cols.74WH, 79WH, col.80WH, cols.82WH-83WH, col.85WH, col.90WH.

48 id. col.83WH; see also cols.87-88WH.

49 id. col.76WH.

50 id. col.74WH; see also col.88WH.

51 id. col.87WH.

52 id. col.81WH.

53 id. col.83WH.

54 id. col.90WH.

55 id. col.76WH.

56 id. col.85WH. 
communities need to be taken back "against the blight of seagulls" 57 - and they called for a coordinated approach and for the sharing of good local practices pertaining to control measures. But the overarching narrative was one that emphasised the need to make people feel safe, to take back control from the gulls, and to bring to an end the "gull wars" apparently raging across the country. ${ }^{58}$ And so, we might say: if the seagull has ever fared well in the popular imagination - and it has indeed had some moments of glory, ${ }^{59}$ amidst a sea of symbolic appearances and myths about gulls that tell of foreboding ${ }^{60}$ - then those days appear to be now almost certainly over. They have been overshadowed by the popular construction of this bird as an urban problem, a worthy target of denigration.

\section{THE REGULATION OF SEAGULLS ACROSS THE UK}

The sense is, therefore, that there is something of an urban gull problem. But Thérèse Coffey, the Parliamentary Under Secretary of State for Environment, Food and Rural Affairs, in responding to MPs in the Commons debate - and in particular to their demands for amendments to wildlife legislation and for an increase in resources available to local authorities to address the issue - stated that " $[t]$ he current legislation provides sufficient powers to take appropriate action to tackle the problems caused by gulls". ${ }^{61}$ Coffey made it clear that where there are problems with gulls in a particular area, then the matter is one for the local authority in question to resolve.

But to what extent do local authorities indeed perceive there to be a problem with urban gulls in their area? And if they do perceive there to be a problem, what measures (if any) do they take in response to this? Whilst local authorities have no statutory duty to do anything about gullrelated problems, some of them quite clearly feel that they ought to be doing something. The reasons for this include the scale of the local problem, ${ }^{62}$ concerns about the reputational costs to the council of inaction, ${ }^{63}$ concerns about the health and safety of the public, ${ }^{64}$ and the desire to 'take back communities' from the gulls. ${ }^{65}$ These all boil down to the construction of the urban-

\footnotetext{
57 id. col.80WH.

58 id. cols.96WH and 74WH.

${ }^{59}$ E.g., the Welsh fable of St Cenydd, in which gulls rescued an infant who had been cast out into the sea in a wicker basket (R. W. Chadd and M. Taylor, Birds: Myth, lore and legend (2016), 269) and the Welsh poem 'Yr Wylan' (The Gull') by Dafydd ap Gwilym, which depicts the gull as a messenger and bringer of love (< http://www.dafyddapgwilym.net/eng/3win.htm $>$ ).

60 See, e.g., M. Wellesley, 'Pity the Seagull' (2015) London Review of Books blog (< https://www.lrb.co.uk/blog/2015/08/24/mary-wellesley/pity-the-seagull/>).

${ }^{61}$ H.C. Debs, op. cit., n10, col.94WH.

${ }^{62}$ E.g. $<$ https://www.herefordshire.gov.uk/info/200145/business/124/pest control services/4>.

${ }^{63}$ E.g., Denbighshire County Council Communities Scrutiny Committee, Meeting Minutes of 23 March 2017, Item 6 Supporting Report: Corporate Approach to Managing "Seagulls" Across the County (Head of Planning and Public Protection), para.10.1, < https://moderngov.denbighshire.gov.uk/mgAi.aspx?ID=10950\#mgDocuments\&LLL=0 $>$.

64 This is the most commonly used justification for taking measures against gulls.

${ }^{65}$ H.C. Debs, op. cit., n10, col.80WH.
} 
nesting gull as an aggressor to be controlled; and the question really is of the regulatory form that this control takes. I therefore decided to examine the models of regulation that local authorities across the UK have adopted in relation to urban-nesting gulls.

I began by examining the websites and publicly-available documents of all 418 principal councils. This was to see, in the first instance, whether there was any reporting of gull-related problems within each area. Where there were references to gulls both in council materials and in local news reports (accessed through online searches), or where there were more than two references in either or the other (and pertaining specifically to gulls within that local area), I sent a freedom of information request to the council in question. In the request, I asked about: the number of complaints about gulls received by the council from 2010-2016; measures taken by the council against gulls since 2010 (such as egg or nest removal) and the cost of such measures; measures taken directly against members of the public since 2010 (such as fixed penalty notices) or to deter them from feeding gulls (such as street signage) and the cost of such measures; and whether the council was using, or had considered using, anti-social behaviour measures in relation to bird-feeding (both of gulls and more generally).

Between early August 2017 and mid-September 2017, I identified and sent freedom of information requests to 75 local councils across the UK in this way: 49 in England (out of a possible 353), 16 in Scotland (out of 32), 9 in Wales (out of 22), and 1 in Northern Ireland (out of 11). I received full replies from 74 councils (with a further one explaining that there would be a delay in response due to a cyber-attack on the council's system ${ }^{66}$ ). The full datasets that were generated through this research are presented in the British Birds journal. ${ }^{67}$ My focus in this article - and in the context of my enquiry here into the socio-legal construction of the 'seagull' - is on the nature of the regulatory measures adopted across the UK. These fall across the two categories of (1) direct and deterrent measures to control and manage urban gulls and (2) direct and deterrent measures adopted in relation to people.

\section{Measures against gulls}

Some authorities reported not taking any measures against urban gulls, on such grounds as that they have no statutory duty to do so (and therefore such action is not budgeted). ${ }^{68}$ Others reported

\footnotetext{
${ }^{66}$ Copeland Borough Council (by email, 6 November 2017).

${ }^{67}$ S. Trotter, 'The Regulation of Urban Gulls across the UK: A study of control measures' (forthcoming) British Birds. The datasets are also available from me directly (s.trotter@,lse.ac.uk).

${ }^{68}$ Gwynedd Council (by email, 8 August 2017); Belfast City Council (by email, 7 September 2017); Portsmouth City Council (by email, 20 September 2017); Eastbourne Borough Council (by email, 19 September 2017); Southend-onSea Borough Council (by email, 3 October 2017); Ipswich Borough Council (by email, 2 October 2017); North
} 
taking friendly measures, to protect gulls and their chicks. ${ }^{69}$ Of those councils that reported taking measures to control gull populations, however, the following measures were reported:

\begin{tabular}{|l|l|}
\hline Measure & Description \\
\hline buildings & $\begin{array}{l}\text { Bird-proofing measures are used to prevent nesting, usually on the rooftops of } \\
\text { buildings. They include the installation of spikes and netting and the use of } \\
\text { repellent gels. }\end{array}$ \\
\hline $\begin{array}{l}\text { Egg and nest } \\
\text { removal }\end{array}$ & $\begin{array}{l}\text { Egg and nest removal means exactly that: removing nests and eggs. To be effective, } \\
\text { a removal programme has to be created, so that the process is repeated throughout } \\
\text { the breeding season. This is because gulls will build new nests and lay replacement } \\
\text { clutches of eggs very quickly.70 In Dumfries and Galloway, for example, the } \\
\text { Council in } 2013 \text { adopted a plan of "weekly egg and nest removal on seven roof- } \\
\text { nesting colonies located on industrial buildings with the aim of intensifying } \\
\text { disruption, forcing gulls to build nests and lay replacement clutches of eggs almost } \\
\text { continuously".71 In 2016, it treated 21 buildings in this way, to clear entire sites. }{ }^{72}\end{array}$ \\
\hline Chick removal & $\begin{array}{l}\text { This is the most controversial measure, as it involves removing chicks from nests } \\
\text { and euthanizing them. It is not always possible; for example, the General Licence } \\
\text { in England does not permit the killing or taking of herring gull chicks. Some } \\
\text { councils have used this measure intensively, however; Dumfries and Galloway } \\
\text { reported a 90\% increase in the number of live chicks removed from 2015 to 2016, } \\
\text { which was attributed to a failure of the public to ask for treatment during the } \\
\text { incubation period and a tendency, rather, to leave it until "after the chicks had } \\
\text { hatched and when more severe problems, such as swooping on people, began".73 }\end{array}$ \\
\hline Shooting of birds \\
of birds of prey \\
gulls.
\end{tabular}

Tyneside Council (by email, 13 October 2017); Bournemouth Borough Council (by email, 13 October 2017); East Devon District Council (by email, 30 August 2017).

${ }^{69}$ E.g., South Lakeland District Council reported taking action in August 2013 at the Coronation Hall in Ulverston to install wire mesh domes to outlets of lead valleys on roof to prevent seagull chicks falling in and dying (by email, 6 October 2017).

${ }^{70}$ Moray Council Corporate Director (Economic Development, Planning and Infrastructure), Report on the Control of Gulls to the Planning and Regulatory Services Committee (6 September 2016), paras.5.3-5.4, <http://www.moray.gov.uk/minutes/data/RR20160906/Item\%2011-Control\%20of\%20Gulls-R.pdf $>$.

${ }^{71}$ Dumfries and Galloway Urban Gull Task Force, Management of Gull Problems in the Town of Dumfries: An overview report by the Urban Gull Task Force for consideration by Dumfries \& Galloway Council, 2016 season (March 2017), 6 (by email, 1 September 2017).

72 id. p.7.

73 id. p. 8.

${ }^{74}$ By email, 16 August 2017. 


\begin{tabular}{|l|l|}
\hline Egg oiling & $\begin{array}{l}\text { This is used to prevent hatching (the aim being that it will stop aggressive behaviour } \\
\text { in gulls as they will not have young nestlings to protect }{ }^{75} \text { ). It is considered to be } \\
\text { less effective than egg and nest removal, because young gulls in their third summer } \\
\text { looking for a breeding site for the following year "are naturally attracted to sites } \\
\text { where other gulls appear to be sitting undisturbed on eggs" - which they will be } \\
\text { doing if the eggs are oiled (or substituted for imitation eggs: see below). }{ }^{76}\end{array}$ \\
\hline Egg replacement & $\begin{array}{l}\text { This involves the replacement of eggs with imitation eggs, with the aim being to } \\
\text { stop aggressive behaviour in gulls defending their young. }\end{array}$ \\
\hline Gull-proof & $\begin{array}{l}\text { This involves the council distributing or making available gull-proof binbags for } \\
\text { households. }\end{array}$ \\
\hline Gull scarers & $\begin{array}{l}\text { Cardiff Council defines these measures as including "[1]oud bangs, screaming } \\
\text { noises, waving streamers... [p]lastic eagle owls, balloons resembling threatening } \\
\text { eyes...[p]roducing gull distress calls and broadcasting across urban areas...[w]ind- } \\
\text { driven, moving structures...".77 }\end{array}$ \\
\hline
\end{tabular}

The focus of these measures is on getting gulls out of 'our' urban spaces. A number of councils reported expending significant time and resources to this end - often running to tens of thousands of pounds per annum ${ }^{78}$ - particularly in the first year of any control programme. Despite this (and despite also the general acceptance that programmes need to be repeated for years to be effective as gulls return to the same spot to nest), many councils reported that they have still not managed to surmount the gull "problem ${ }^{79}$ and that they are now trying different tactics. In Dumfries and Galloway, for example, the concern now is to target "roofs that are considered by the gulls to be a safe haven" and that are inaccessible to contractors and property owners. ${ }^{80}$ Carlisle City Council has a similar strategy; it reported that gull monitoring "started in March [2017] to identify highly populated gull areas", with the idea being to "build up knowledge from complaints received in 2017 and....allow the council to give advice to businesses whose premises are a refuge for gulls." ${ }^{\prime 1}$

\footnotetext{
${ }^{75}$ Moray, op cit., n70, para.5.3.

${ }^{76}$ Dumfries and Galloway, op cit., n71, Annex A. See also Cardiff Council Environmental Scrutiny Committee Report

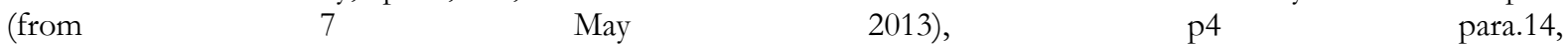
< http://cardiff.moderngov.co.uk/Data/Environmental $\% 20$ Scrutiny $\% 20$ Committee/20130507/Agenda/Urban $\% 2$ 0Guls $\% 20 \% 2812.68 \mathrm{M} \% 29 . \mathrm{pdf}>$.

77 Cardiff, id., p. 5 para. 15.

78 E.g. Dumfries and Galloway Council ( $£ 25,700$ on gull management in 2016, down from $£, 42,000$ in 2012 [by email, 1 September 2017]); Bath and North East Somerset Council ( $£ 85,000$ in 2016/17 [by email, 12 October 2017]).

${ }^{79}$ This, perhaps, is unsurprising. See P. Rock, 'Urban Gulls: Why Current Control Methods Always Fail' (2013) 82 Rivista Italiana di Ornitologia 58.

${ }^{80}$ Dumfries and Galloway Council, Report by the Director of Economy, Environment and Infrastructure to the Environment, Economy and Infrastructure Committee on Dumfries Gull Project 2015 (1 July 2016), paras.3.15-3.16. $<$ http://egenda.dumgal.gov.uk/aksdumgal/images/att41311.pdf $>$.

${ }^{81}$ By email, 15 September 2017.
} 
In Cardiff, which has a very large urban gull colony, ${ }^{82}$ the Council considers that gulls are, quite simply, "unlike all of the other "problem species"” ${ }^{83}$ There are two reasons, it suggests, as to why this is the case: "First, gulls are not confined to a single centre of activity. They move widely and are perfectly capable of making a round trip of $100 \mathrm{~km}$ in search of food in only a few hours. Second, they are considerably more intelligent than most and despite the best efforts of pest control agencies to deter or remove them, colonies have continued to expand." ${ }^{84}$ In Denbighshire County Council, meanwhile, the Head of Planning and Public Protection concluded in a Report to the Communities Scrutiny Committee that " $[t]$ here is a risk that the proposed actions will have very little impact, but the actions are in part about the Council seeking to do what it can and in part about educating the general public." ${ }^{85}$

\section{Measures in relation to people}

This notion of 'educating' the public brings us to the gull-related measures that have been adopted in relation to people and that are about deterring people from feeding the gulls. The measures that councils use in this regard are:

\begin{tabular}{|l|l|}
\hline Measure & Description \\
measures & $\begin{array}{l}\text { Informational measures used to discourage people from feeding birds include } \\
\text { signage (for example, posters saying 'feed the bins, not the birds' along seafronts), } \\
\text { public awareness campaigns, and leaflets. These measures are in addition to the } \\
\text { information that is offered about gull control on council websites. Some councils } \\
\text { (East Devon, Barrow, and Dumfries and Galloway) have, furthermore, held Seagull } \\
\text { Summits, enabling people to gather and propose solutions to the 'seagull problem'. }\end{array}$ \\
\hline $\begin{array}{l}\text { Measures in } \\
\text { relation to local } \\
\text { businesses }\end{array}$ & $\begin{array}{l}\text { These include advisory measures (about the management of food waste, for } \\
\text { example) and anti-bird-feeding posters distributed to local businesses to display on } \\
\text { their premises. }\end{array}$ \\
\hline $\begin{array}{l}\text { General advisory } \\
\text { letters }\end{array}$ & $\begin{array}{l}\text { General advisory letters are used by some councils to offer pre-emptive advice to } \\
\text { households in particular areas about bird control measures or to offer guidance on } \\
\text { the legal status of gulls in contexts of complaints from nearby households. }\end{array}$ \\
\hline $\begin{array}{l}\text { Direct contact } \\
\text { with bird-feeding } \\
\text { individuals }\end{array}$ & $\begin{array}{l}\text { A number of councils reported sending 'warning' or 'informal' letters to individuals } \\
\text { who had been caught feeding the gulls (or, and less frequently, organising a meeting } \\
\text { with them). Moray Council noted also that it has a reporting mechanism on its }\end{array}$ \\
\hline
\end{tabular}

82 P. Rock, Roof-Nesting Gulls in Cardiff: Follow-up Survey conducted in May 2011, Report for Cardiff County Council (2011), $<$ http://cardiff.moderngov.co.uk/Data/Environmental $\% 20$ Scrutiny $\% 20$ Committee $/ 20130507 /$ Agenda/Urban $\% 2$ $0 \mathrm{Guls} \% 20 \% 2812.68 \mathrm{M} \% 29 . \mathrm{pdf}>$.

${ }^{83}$ Cardiff, op cit., n76, p.3 para.9.

84 id. p3 para.9.

${ }^{85}$ Denbighshire, op cit., n63, para.10.3. 


\begin{tabular}{|c|c|}
\hline & $\begin{array}{l}\text { website, so that individuals can report any incidents of bird-feeing that they have } \\
\text { witnessed. }{ }^{86} \text { This triggers a visit to the 'offending' individual by the Community } \\
\text { Warden. }\end{array}$ \\
\hline $\begin{array}{l}\text { Tenancy } \\
\text { Agreement } \\
\text { notices }\end{array}$ & $\begin{array}{l}\text { The Highland Council reported that it had occasionally issued tenancy agreement } \\
\text { notices "to tenants who have been causing a nuisance by feeding wild birds, } \\
\text { including seagulls". }{ }^{87}\end{array}$ \\
\hline $\begin{array}{l}\text { Anti-social } \\
\text { behaviour } \\
\text { measures }\end{array}$ & $\begin{array}{l}\text { Several authorities, primarily in England and Wales, reported either using or } \\
\text { considering the use of anti-social behaviour measures to target bird-feeding by } \\
\text { individuals. The notion of 'anti-social behaviour' was itself propelled into British } \\
\text { policy discourse by the New Labour government in the } 1990 \text { s, which introduced a } \\
\text { range of controversial measures that were targeted at behaviour that was } \\
\text { constructed as 'anti-social'. } 88 \text { The powers that authorities have in relation to 'anti- } \\
\text { social behaviour' have since been expanded and the mechanisms that are available } \\
\text { to them to deal with this behaviour have been consolidated. In England and Wales } \\
\text { this is by the Anti-social Behaviour, Crime and Policing Act } 2014 \text { ('the } 2014 \text { Act'). } \\
\text { Two of the measures that it introduced - Community Protection Notices (CPNs) } \\
\text { and Public Spaces Protection Orders (PSPOs) - were cited by authorities here: }\end{array}$ \\
\hline $\begin{array}{l}\text { Community } \\
\text { Protection } \\
\text { Notices (CPNs) }\end{array}$ & $\begin{array}{l}\text { Under Section 43(1) of the } 2014 \text { Act, local authorities in England and Wales can } \\
\text { issue CPNs to specified individuals [or businesses] if satisfied on 'reasonable } \\
\text { grounds' that '(a) the conduct of the individual or body is having a detrimental } \\
\text { effect, of a persistent or continuing nature, on the quality of life of those in the } \\
\text { locality, and (b) the conduct is unreasonable'. Such notices are used to impose } \\
\text { requirements that, for example, the individual stops doing the thing that is specified } \\
\text { in the notice. } 12 \text { councils reported having used CPNs (or warning notices, which } \\
\text { precede the serving of a CPN) in relation to bird-feeding. }\end{array}$ \\
\hline $\begin{array}{l}\text { Public Spaces } \\
\text { Protection } \\
\text { Orders (PSPOs) }\end{array}$ & $\begin{array}{l}\text { Under Section } 59 \text { of the } 2014 \text { Act, local authorities can make a PSPO if satisfied } \\
\text { on 'reasonable grounds' that firstly, '(a) activities carried on in a public place within } \\
\text { the authority's area have had a detrimental effect on the quality of life of those in } \\
\text { the locality, or (b) it is likely that activities will be carried on in a public place within } \\
\text { that area and that they will have such an effect' and secondly that the effect or likely } \\
\text { effect of the activities '(a) is, or is likely to be, of a persistent or continuing nature, }\end{array}$ \\
\hline
\end{tabular}

\footnotetext{
86 By email, 22 August 2017. The form for reporting seagull-feeding is at $<$ https://online.moray.gov.uk/form/auto/asb ext $>$.

${ }^{87}$ By email, 5 September 2017.

88 See further C. Johnstone, 'After the Asbo: Extending control over young people's use of public space in England and Wales’ (2016) Critical Social Policy 36(4), 716-726.
} 


\begin{tabular}{|l|l|}
\hline (b) is, or is likely to be, such as to make the activities unreasonable, and (c) justifies \\
the restrictions imposed by the notice'. The Order identifies a public space and \\
stipulates requirements or prohibitions as to what can be done in that space. It can \\
have effect for up to three years. ${ }^{89}$ At the time of writing, East Devon District \\
Council and West Dorset District Council have introduced PSPOs prohibiting \\
gull-feeding in defined areas..$^{90} 4$ further local authorities reported considering this \\
measure in relation to bird-feeding in general; and two completed public \\
consultations in September-October $2017:$ Wyre Council on a PSPO to prohibit \\
gull-feeding in three areas and Havant Borough Council to prohibit pigeon-feeding \\
in three town centre locations.
\end{tabular}

What to make of these measures? Perhaps we should begin with the most obvious point, which is that these are all modes of regulation. The regulatory undertone is there, for example, in the advisory letters that are sent out to households and contain subtle reminders that gulls are attracted by "inappropriate bird-feeding and litter" and that Fixed Penalty Notices can be issued to anyone seen dropping litter. ${ }^{11}$ It is there in the warning letters that report that there have been complaints to the Council about bird-feeding by the individual in question. ${ }^{92}$ It is there in the patrolling of public spaces by officers "trained [in] the application of the Litter Acts". ${ }^{93}$ And it is there, too, in measures like Moray Council's online complaint mechanism - a mechanism which enables individuals to report "feeding activity" that they have witnessed, and that leads to the reported individual being visited by the Community Warden. ${ }^{94}$ In a 2016 report to Moray Council's Planning and Regulatory Services Committee, it was noted that "few individuals have been willing to be named witnesses" via this online mechanism, meaning that "the warden will have to witness the individual deliberately targeting the gulls as the recipient of the food being provided to enable more punitive action to be taken". ${ }^{95}$ The implication was that this action may consist, in some cases (" $[\mathrm{w}]$ here there is evidence that deliberate feeding of gulls is being carried out and the responsible person refuses to desist to prevent problems caused by gulls") in the application of the anti-social behaviour legislation (here, the Antisocial Behaviour etc. (Scotland) Act 2004))..$^{96}$

\footnotetext{
89 Anti-Social Behaviour, Crime and Policing Act 2014, s. 60.

${ }^{90}$ East Devon, op cit., n14, s. 4; West Dorset Anti-social Behaviour Related Public Spaces Protection Order 2018, s. 2.

91 This was a feature of a sample advisory letter that I received from Inverclyde Council (by email, 9 August 2017).

${ }^{92}$ E.g., a sample warning letter from Barrow Borough Council opens with "I regret to inform you that this department has received complaints relating to food being thrown into back yards/onto gardens and the back street which is intended for the birds/seagulls..." (by email, 18 August 2017).

${ }_{93}^{3}$ Dumfries and Galloway, op cit., n80, paras.3.20-3.21.

94 Moray, op cit., n70, para.5.7.

95 id. para.5.7.

96 id. para.6.3.
} 
This turn towards the use of anti-social behaviour law is a more general feature of the gull-related measures that have been taken in relation to people, and it involves the construction of ideas of 'bad behaviour' and 'quality of life' that also underpin the other measures taken here and that are discussed in further detail in the pages below.

As part of this regulatory approach, local authorities have to construct the targets of their regulation; and often children are prime contenders for this status, particularly when it comes to general modes of regulation, like education and publicity campaigns. In Moray Council, for example, schoolchildren have been implicated as "deliberately [feeding] the birds to encourage the swooping and dive bombing". ${ }^{97}$ Reports to the Environment and Protective Services Committee of the Comhairle Nan Eilean Siar (the Council for the area comprising the Outer Hebrides) meanwhile indicate that the enforcement aspect of an anti-litter campaign that was planned in 2009 to deal with seagull nuisance in Stornoway was delayed as "it was considered essential to carry out an education campaign first, especially in relation to school children". ${ }^{98}$ The Dumfries and Galloway Urban Gull Task Force too recommended to Dumfries and Galloway Council in 2017 that it "continue with their advertising campaign to discourage the hand-feeding of gulls by children and tourists in particular", on the grounds that "[t]his type of human behaviour can lead to undesirable food stealing behaviours in the gulls, and should be strongly discouraged". ${ }^{99}$ The category of the 'child' serves in this way, and by dint of its developmental orientation, to enable the articulation of a normative 'educative' approach. This is because by casting a particular form of behaviour - bird-feeding, for example - as 'improper' behaviour that is linked to an (immature) child, a counter-vision - of 'proper', 'mature', non-bird-feeding behaviour - is necessarily articulated too. The same applies in relation to the category of the 'tourist'; for the tourist is necessarily a visitor, an 'other' who is not fully versed in the mode of being of the place that she is passing through, and therefore the invocation of the tourist justifies the simultaneous articulation of the standards and rules that govern the mode of being of the place in question (and against which her behaviour is assessed). All this serves to contribute to the intriguing phenomenon that we see here, which is that in the name of regulating seagulls - the birds that are 'behaving badly' people are being regulated too.

\section{'BAD' BEHAVIOUR}

\footnotetext{
97 id. para.5.7.

98 Comhairle Nan Eilean Siar Director of Development, Report to the Environment and Protective Services Committee, Nuisance from Seagulls in Stornoway (24 August 2010), para.2.4, < http://www.cnesiar.gov.uk/committees/environmental/agendas/august2010/Seagulls2010.pdf>.

${ }^{99}$ Dumfries and Galloway, op. cit., n71, p15.
} 
From the measures described - both those taken directly against gulls and those taken in relation to people - two accounts of 'bad behaviour' emerge. There is firstly an account of the 'behaviour' of the gulls. This builds on the vision of seagulls set out in the first part of this article. Thus as it was put in a 2016 report produced within Moray Council, " $[\mathrm{g}]$ ulls can cause annoyance and distress to the public in several ways[:] direct stealing of food from people's hands in town centre areas; aggressive behaviour e.g. swooping and dive bombing by parent birds in the defence of young birds; noise by calling/screeching particularly after first light in residential areas; contamination of cars, buildings, washing and people; litter caused by gulls foraging in open bins and other sources for food that is not secured or out of reach...". ${ }^{100}$ The report goes on to note that "[i]t is unusual for gulls to be aggressive outwith the hatching season unless they have learned an easy food source e.g. by taking from humans (usually a child) hands [sic.] when eating outdoors...". ${ }^{101}$ Other council bodies have come up with similar accounts; for example, the Dumfries and Galloway Urban Gull Task Force describes all the problems that are "associated with the presence of gulls" (again in terms such as 'stealing', 'aggressive' behaviour, and 'ripping open' binbags). ${ }^{102}$ The way in which gulls mess up the "public realm" and "pester" people for food ("[t]hey have learned our habits" and "will actually take food out of someone's hand") was also considered in a Denbighshire County Council report in March 2017, alongside a number of other problems that the gulls residing in Denbighshire are purportedly responsible for. ${ }^{103}$ Scarborough Borough Council meanwhile encourages residents to report "gull attacks" by completing an online "seagull mugging and nuisance report form". ${ }^{104}$ Between March and August 2016, 22 such "gull muggings" were reported in this way. ${ }^{105}$

But if we think about these 'behaviours' - these apparently 'bad' 'behaviours' - we may also conclude that they are natural, adaptive behaviours. Research in this field indicates, for example, that gulls will only tend to be aggressive when they perceive a threat and when they are trying to protect their nestlings; it is otherwise in their interests to remain as close as possible to their nests. ${ }^{106}$ And some of the broader issues here - like rubbish being scattered and bins being

\footnotetext{
100 Moray, op. cit., n70, para.3.3.

101 id. para.3.3.

102 Dumfries and Galloway, op cit., n71, p5.

103 Denbighshire, op cit., n63, para.4.3.

$104<$ https://www.scarborough.gov.uk/seagulls $>$.

105 Scarborough Borough Council, Overview and Scrutiny Board: Agenda for meeting on 7 September 2016, 13 $<$ https://democracy.scarborough.gov.uk/documents/g8197/Public\%20reports\%20pack\%2007th-Sep2016\%2014.00\%20Overview\%20and $\% 20$ Scrutiny $\% 20$ Board.pdf? T=10 > .

106 See, e.g., J. Burger and M. Gochfeld, 'Behavioural responses to human intruders of herring gulls (Larus argentatus) and great black-backed gulls (L. marinus) with varying exposure to human disturbance' (1983) 8 Behavioural Processes, 328; N. Tinbergen, The Herring Gull's World: A Study of the Social Behavior of Birds (1971 [1960]), ch.19.
} 
'raided ${ }^{107}$ - are a consequence of our own behaviours and actions upon our urban environments. Nevertheless, what we have here is a portrayal of 'annoying', 'aggressive', 'stealing', and 'pestering' behaviours. The 'bird' behaviour becomes 'bad' behaviour, and we begin to see the creation of the idea that the urban gull is not only an urban problem, but also an urban pest. All that is required for this to take hold is the articulation of a notion of 'conflict' between 'our' population and the gull population; ${ }^{108}$ thus the gulls come to be seen as being what Chris Philo has elsewhere suggested that animals sometimes do become: "transgressive of the socio-spatial order which is created and policed around them by human beings, becoming 'matter out of place' in the process". ${ }^{109}$

The urban-nesting pigeon - usually described as the 'feral' pigeon, and seemingly beloved by very few ${ }^{110}$ - has suffered a comparable fate in the face of a similar discursive construction, and Colin Jerolmack has written about this at some length in a fascinating book called The Global Pigeon. ${ }^{111}$ But there is also something highly distinctive about the discourse around gulls. For whereas pigeons are often cast as being unclean and disruptive to a particular conception of civility, ${ }^{112}$ urban gulls are also cast as being aggressive - as having the capacity to attack. Allocations of blame and questions of responsibility about the 'behaviour' of gulls are even more pertinent here, therefore, ${ }^{113}$ and this is reflected in the close association that is drawn between the account of the 'bad' 'behaviour' of the gulls and an account of the 'bad' (because somehow abetting) behaviour of humans.

This latter account underlies the regulatory measures that are taken in relation to people in the name of regulating and controlling the gull population. These measures involve the construction of bird-feeding by humans as something that not only exacerbates the behaviour of the birds but that is 'bad' and risky behaviour in its own right. For example, one of the recommendations made by the Denbighshire County Council Communities Scrutiny Committee when it addressed the question of "managing 'seagulls' across the county" in March 2017 was that a "communication

107 See Cardiff, op cit., n76, para.10.

108 See P. Olsen, Australia's Pest Animals: New Solutions to old problems (1998), 13.

109 C. Philo, 'Animals, Geography, and the City: Notes on Inclusions and Exclusions' in Animal Geographies: Place, Politics, and Identity in the Nature-Culture Borderlands, eds. J. Wolch and J. Emel (1998), 52.

110 See, e.g., B. Allen, Pigeon (2009); R. Piper, Pests: A Guide to the World's Most Maligned, Yet Misunderstood Creatures (2011), 244-248; S. Moss, Wild Kingdom: Bringing Back Britain's Wildlife (2016), 207-210; M. Merritt, A Sky Full of Birds: In Search of Murders, Murmurations and Britain's Great Bird Gatherings (2016), 98-99.

111 C. Jerolmack, The Global Pigeon (2013), 8-11, ch.2.

112 id.; C. Jerolmack, 'How Pigeons Became Rats: The Cultural-Spatial Logic of Problem Animals' (2008) 55 Social Problems 72; M. P. Escobar, 'The power of (dis)placement: pigeons and urban regeneration in Trafalgar Square' (2014) 21 cultural geographies 363.

113 See, e.g., Cathie Kelly v Riverside Inverclyde (Property Holdings) Limited [2014] CSOH 86, in which an employee of a business centre in Greenock brought a personal injury claim against the owners, occupiers, and operators of the building following an 'attack' on her by a gull that "swooped at her with its wings outstretched" as she left her office one day to fetch lunch (para.1). Her action failed, because it was not possible to establish on the balance of probabilities that the offending gull came from the roof of her workplace. 
campaign" be undertaken "to educate residents and visitors not to feed the seagulls, drawing to their attention the dangers to both humans and the seagulls themselves of this practice (similar to the approach taken by zoos)". ${ }^{114}$ Meanwhile a sample warning letter used by Barrow Borough Council to deal with individuals who have been reported for feeding birds in their gardens outlines a number of hazards posed to neighbours as a consequence of the individual's bird-feeding habits, such as how "[b]ird droppings can cause a danger by slipping and can also cause health hazards to people living nearby in terms of disease, as well as causing damage to buildings". ${ }^{115}$ The letter concludes with the following statement: "I trust that if this [concern about bird-feeding] applies to yourself, you will consider the issues raised in this letter and cease to feed the birds in this way in the interests of Public Health and good neighbourliness". ${ }^{116}$ Not only is bird-feeding presented in this letter as being risky for individuals, but it is also cast as being antithetical to 'good neighbourliness' and cooperation in the community. ${ }^{117}$

The strongest articulation of this idea that bird-feeding is bad in the sense of its implications for the community occurs in the use of anti-social behaviour legislation, which a number of councils in England and Wales reported turning to in this context. ${ }^{118}$ The basic underpinning idea here is that bird-feeding becomes anti-social because it encourages hostile behaviours on the part of the birds. Wyre Council, for example, in response to the question of whether the council had issued any CPNs in relation to the feeding of gulls or any other birds, noted that "we have advised that action could be taken using [anti-social behaviour] legislation in some cases". ${ }^{119}$ And the response to my further query as to the sort of cases that would indeed lead to this was: "Where the council receives a complaint from a neighbour that the feeding of gulls is causing harm or distress we would investigate the circumstances and a decision would be made on a case by case basis. The type of issue we may look at for example is where feeding is such that it attracts significant numbers to the house and the neighbour cannot walk out of their

\footnotetext{
114 Denbighshire County Council Communities Scrutiny Committee, Meeting Minutes of 23 March 2017 $<$ https: //moderngov.denbighshire.gov.uk/mgAi.aspx?ID=10950\&LLL=0 $>$.

115 By email, 18 August 2017.

116 id.

117 This narrative of cooperation runs more generally throughout the gull-related measures taken in relation to people. For example, a sample general advisory letter that I received from Inverclyde Council emphasised that "[i]f all owners of buildings which have (or may attract) roof-nesting Gulls took appropriate measures, it would be easier to reduce or break up the Gull colonies and the whole community would benefit...” (by email, 9 August 2017).

118 None of the Scottish or Northern Irish local authorities reported resorting to anti-social behaviour measures, though one Scottish council (Moray Council) was not averse to using anti-social behaviour legislation in this context (see below).

${ }^{119}$ By email, 12 October 2017.
} 
house without being attacked. This is just an example but in order for us to take action it would have to satisfy the legal test for anti-social behaviour." 120

There are quite a few questions that we might ask about this construction of the act of 'bird-feeding' as a form of 'bad' behaviour. The construction itself is particularly interesting in the context of research that points towards the social significance and benefits of human-animal interaction generally and bird-feeding more specifically. ${ }^{121}$ Colin Jerolmack, for example, in his ethnographic research of a public park in New York, describes how pigeon-feeding in that park offered many possibilities for interaction (between birds and people and between people) that rendered it a socially significant act and one that '[helped] satisfy pedestrians' desire for copresence". ${ }^{122}$ As he puts it: "the sociability that people can achieve through pigeon feeding especially for solitary pedestrians - demonstrates that mundane encounters with animals can offer opportunities for the kind of informal, bounded forms of copresence that urban sociologists claim enrich people's experiences of the sidewalk and combat feelings of social isolation". ${ }^{123}$ And, we might add, in a context in which there seems to be something of an epidemic of loneliness plaguing what has so far been of the twenty-first century, ${ }^{124}$ what could be said against that?

Elsewhere, the act of bird-feeding has itself been framed as a matter of individual autonomy, as in Germany, where the Constitutional Court has ruled that feeding pigeons in public parks is protected as a right under the general freedom of action set out in Article 2(1) of the German Basic Law. ${ }^{125}$ In 2015 and 2017, two local authorities in North Wales (Conwy County Borough Council and Denbighshire County Council) alluded to this in noting that measures to curb bird-feeding might affect individual rights. ${ }^{126}$ Neither of the councils took this point any further, however; and in more recent public communications they have reverted to the message that feeding gulls is simply bad for local residents and for the local area more generally. ${ }^{127}$ The dominant construction of gull-feeding by local authorities in the UK remains one that casts this

\footnotetext{
120 By email, 18 October 2017.

${ }^{121}$ E.g., D. T. C. Cox and K. J. Gaston, 'Urban Bird Feeding: Connecting People with Nature' (2016) 11 PLOS One 1; S. J. Reynolds, J. A. Galbraith, J. A. Smith, and D. N. Jones, 'Garden Bird Feeding: Insights and Prospects from a North-South Comparison of This Global Urban Phenomenon’ (2017) 5 Frontiers in Ecology and Evolution 1, at 5-6. 122 Jerolmack, op. cit., n111, p27.

123 id. 442.

${ }^{124}$ E.g., O. Sagan and E. Miller (eds.), Narratives of Loneliness: Multidisciplinary Perspectives from the $21^{\text {st }}$ Century (2017).

${ }^{125}$ BVerfGE 54 at 143. See further K. Möller, The Global Model of Constitutional Rights (2012), ch.4.

126 See The Telegraph, 'Seagull crackdown halted over fears it could offend people's religious rights' (21 July 2015) $<\underline{\text { https://www.telegraph.co.uk/news/religion/11753775/Seagull-crackdown-halted-over-fears-it-could-offend- }}$ peoples-religious-rights.html>; Denbighshire County Council Communities Scrutiny Committee, Meeting Minutes of 23 March 2017, Item 6 Appendix 1: Draft Seagull Action Plan - Wellbeing Impact Assessment Report, 9, $<$ https://moderngov.denbighshire.gov.uk/mgAi.aspx?ID=10950\#mgDocuments\&LLL=0 $>$.

127 See <http://www.conwy.gov.uk/en/Resident/Environmental-problems/Pest-and-Bird-Control/Seagulls-andPigeons.aspx $>$ and <https://www.denbighshire.gov.uk/en/resident/news/march-2018/Y-Cyngor-yn-Galw-arBobl-i-Beidio-\%C3\%A2-Bwydo'r-Gwylanod.aspx $>$.
} 
feeding as bad, anti-social behaviour, therefore. Alternative framings - such as those that would examine gull-feeding through the lenses of sociability or individual autonomy - are sidelined; and so also are broader questions of the welfare of urban gulls, of the nature of the relationship between urban gulls and people, and of our responsibilities in relation to these birds. ${ }^{128}$ The construction of the 'seagull' that is reflected in the accounts of the 'bad' 'behaviour' of gulls and of the anti-social nature of bird-feeding by humans rather supplies the framing that underpins that justifies - the regulatory approaches adopted by local authorities across the UK in this area. And these accounts, in turn, with their invocation of the 'bad' and the 'social', sit within the context of a broader story that is to be told here, which is a story of the way in which underlying the framework of the regulation of seagulls in the UK is also a normative idea of public space, such that the accounts of 'bad behaviour' that we have seen here are an expression of a vision of public space.

\section{THE CONSTRUCTION OF PUBLIC SPACE}

In the UK, the move to consider the gull as a problem - a pest - began when gulls began to establish themselves in big colonies in 'our' urban spaces. There has been little attention to the possibility of the cohabitation of urban gulls and people in the documents generated by local authorities (though it is a constant refrain elsewhere in the literature ${ }^{129}$ ). Where the possibility of gulls remaining in towns and cities has been articulated, this is only because they are deemed part of the 'place'. In a report produced within Denbighshire County Council in March 2017, for example, it was noted that there was a need to recognise "that many people like 'seagulls", they are a traditional part of our seaside environment, and in their own right are impressive birds". ${ }^{130}$ In other words, they are a part of our conception of a particular 'place' - the place of the seaside. This was put even more firmly by the Council's Head of Planning and Public Protection the same day: "[m]any seagulls are protected and we need to be mindful that many see them as being an integral and traditional part of our coastal communities. What we want to see is a change in people's behaviour so that gulls are not fed from food and refuse left on our streets". ${ }^{131}$ Wyre Council, in launching its Consultation on a PSPO to prohibit gull-feeding in August 2017 meanwhile started by noting that " $[\mathrm{t}]$ he council recognises that seagulls are a welcomed symbol of

\footnotetext{
${ }^{128}$ For a discussion of these latter points, see C. Palmer, 'Placing Animals in Urban Environmental Ethics' (2003) Journal of Social Philosophy 34(1), 64-78.

${ }^{129}$ See, e.g., Moss, op. cit., n110, p206-207.

${ }^{130}$ Denbighshire, op cit., n63, para.4.4.

$131<$ https://www.denbighshire.gov.uk/en/resident/news/march-2017/Managing-seagulls-in-Denbighshirecommunities.aspx $>$.
} 
the British seaside" (and then went on to state that "however reported problems associated with seagulls are on the increase"). ${ }^{132}$

On the one hand, then, seagulls are seen as being a part of particular public places - as characterising seaside places. On the other hand, there is a striving for their control and for the control of interactions between gull populations and human populations. The ethos of control that is reflected in the measures that are taken directly against urban gulls spills on over into the measures that are taken in relation to people in the name of regulating gulls; and this culminates in the turn towards anti-social behaviour measures, which is where we find the most forceful expression of the vision of public space that underpins the regulatory measures taken in this area more generally. East Devon District Council has led the way in this regard, with its Seashores and Promenades PSPO of 2017 stipulating that 'A person shall be guilty of an offence [of feeding seagulls] if, at any time, he provides or deposits food for consumption by seagulls on the promenades, beaches and/or foreshore within the administrative area of East District Council unless he has reasonable excuse for doing so'. ${ }^{133}$ The fixed penalty for this is $f^{8} 80$, though the Council states on its website that "[a]ny enforcement [of the PSPO] will be proportionate and will focus primarily on advice and education" and that fines will be reserved for "cases where there is sufficient evidence of harm and consequence". ${ }^{134}$

At the time of their response to my freedom of information request, East Devon District Council stated that " $[\mathrm{n}] \mathrm{o}$ fines have needed to be issued and we have received no reports of people not complying with the requirements". ${ }^{135}$ But to focus on the question of fines is to miss the vital point here, which is that the very existence of the Order is in itself a form of discipline, and one that necessarily involves the articulation and enforcement of a particular vision of what 'public space' is and what being in public space entails. It is this disciplinary quality that has proved tempting for other local authorities in the context of bird-feeding too; within Denbighshire County Council, for example, it has been considered that although enforcing a law against feeding seagulls would pose some practical problems, such a law would nevertheless have merit in "sending out a strong message to residents and visitors alike that the practice [of feeding gulls] would not be welcomed or tolerated". ${ }^{136}$

\footnotetext{
$132<$ http://www.wyre.gov.uk/info/200310/streets and neighbourhood/1152/>.

133 East Devon, op cit., n14, s. 4.

$134 \quad<$ http://eastdevon.gov.uk/consultation-and-surveys/dog-controls-and-seagull-public-space-protection-orderconsultation $/>$.

135 By email, 30 August 2017.

136 Denbighshire, op cit., n114.
} 
The articulation, through a PSPO, of behaviour that is not welcomed or tolerated in a particular area - and of what being in public means, therefore - is enabled, in part, by the notion of 'quality of life' that underpins the making of a PSPO in the first place. Part of the legal test that an authority must meet in order to make a PSPO is that the activities in question and that are carried on within a public space 'have had a detrimental effect on the quality of life of those in the locality' (or that they are likely to be carried on within that space and have such an effect). ${ }^{137}$ Of course the trouble with this notion of 'quality of life' is not only its inherent subjectivity ${ }^{138}$ but that it inevitably transcends any defined public space, meaning that through this mechanism local authorities are enabled to construct an ethos about quality of life that takes them well beyond the 'public spaces' that they simultaneously define. This is especially exacerbated in the context of our case of the gull because, as has been pointed out in various committee meetings up and down the country, birds do not observe local authority boundaries, meaning that a bounded approach to the issue is not really possible. ${ }^{139}$

But more than this, PSPOs here entail the collapse of the socio-legal constructions of 'antisocial behaviour' and 'seagull' into one - a collapse that is already anticipated by the other regulatory measures adopted in relation to gulls but that is seen more keenly here. This is because a PSPO prohibiting bird-feeding presupposes, by definition, that this activity, because of its presumed association with gulls in the locality, is detrimental to the quality of life in that locality. As the Community Safety and Access Portfolio Holder for West Dorset District Council put it, when the West Dorset Anti-Social Behaviour Related PSPO came into force in April 2018: "[t]hese measures aim to reduce anti-social behaviour still further and reduce the problem of aggressive gulls". ${ }^{140}$ Two birds with one stone, it may seem, then; but the construction of bird-feeding as antisocial is also wholly conditional on the prior construction of the badly behaving gull. The objective of the localised forms of regulation that are implemented here comes to be one of eliminating the possibility of confrontation with a gull; and 'public space' goes from being a space of encounter to a space that is to be free of the possibility of being disturbed by a gull. And the point is even narrower than that, really, for the problem being addressed by the bulk of the gull-related measures taken in relation to people is that of the deposition of food that would be possibly consumed by a gull.

The task of the multiple forms of regulation that are instituted to deal with the 'seagull problem', then - both the measures that are taken against gulls and the measures that are taken

\footnotetext{
137 Anti-social Behaviour, Crime and Policing Act 2014, s. 59(2).

138 See K. J. Brown, 'The hyper-regulation of public space: the use and abuse of Public Spaces Protection Orders in England and Wales' (2017) 37 Legal Studies 543, at 546-47.

${ }^{139}$ See, e.g., Denbighshire, op cit., n114.

$140<$ https://news.dorsetforyou.gov.uk/2018/04/20/ban-on-feeding-gulls/>.
} 
against people in the name of regulating gulls - comes to be one of at least seeming to lessen the possibility of an encounter with gulls and of thereby alleviating feelings of potential insecurity in relation to the 'bad' 'behaviour' of gulls. Insofar as this involves the use of anti-social behaviour legislation, it represents quite clearly an instance in the broader development of the criminal law that Peter Ramsay has traced: the development of an increasing orientation towards "[protecting] our subjective feelings of security more directly than in the past". ${ }^{141}$ But there is also something quite distinctive about the 'quality of life' agenda that is pushed more generally through the gullrelated regulatory measures here; and this is something that takes us beyond the ethos of alleviating insecurity that Ramsay highlights in his own analysis. ${ }^{142}$ We can see this more clearly if we consider some of the points put forward in the 'Draft Seagull Action Plan Wellbeing Assessment Report' produced by Denbighshire County Council in 2017, which assessed the impact of gull-related control measures on the 'wellbeing goals' of the county. In that document, it was pointed out - in the consideration of the positive consequences of limiting the 'impact' of seagulls - that "[i]f seagulls are controlled then town centres are more attractive to eat out/socialise in" and that if seagulls are controlled "people will feel more confident in going for a walk in town centres". ${ }^{143}$ These considerations are about more than the feelings of subjective security that are the target of the regulatory measures discussed by Ramsay in his study, though that notion of subjective security is also articulated in this context (as 'confidence'). Rather, the principal target here is the town centre. The object is one of setting out a vision of the town centre; of encouraging people into the town centre; and of stimulating spending in the town centre. The construction of the badlybehaved seagull - of a gull that needs to be controlled - is directly linked to this vision, and therefore also to the accompanying construction of the individual as a consumer. And so the seagull comes to underpin and enable a normative construction not only of public space but also of the individuals who inhabit that space.

We come to see, then, that not only is 'nature', as represented in the urban gull, pushed out of public space (unless the gull can be co-opted into a vision of the place of the seaside and cast as symbolising it) but that the construction of the figure of the gull is bound up in a normative idea of public space. And the regulatory structure that takes hold around seagulls in this way - a regulatory structure that is predicated on a socio-legal construction of the 'seagull' and an associated vision of 'bad behaviour' - reveals something deeper too. This is that in the delineations of 'public space' that occur through the regulatory measures adopted, the very idea of public space

\footnotetext{
141 P. Ramsay, The Insecurity State: Vulnerable Autonomy and the Right to Security in the Criminal Law (2012), 2. 142 id. Ch. 10.

${ }^{143}$ Denbighshire, op cit., n126, p3, p5.
} 
collapses. For in the moment that authorities express and define what 'public space' is and what being in that space entails, the very idea and possibility of public space as a space of encounter necessarily and unavoidably vanishes.

\section{CONCLUSION}

In his classic essay, called 'Why look at animals?', John Berger challenges us to think about what it is of ourselves that we see when we look at an animal. He asks us to think about what it is that we see, for example, when we look at an animal in a zoo enclosure: an animal that has been withdrawn from its own life and entered into a spectacle so that we can observe that which we have isolated ourselves from (animals in everyday life). ${ }^{144}$ Writing a couple of years prior to Berger, Frank Graham similarly concluded his book Gulls: A Social History with the point that the "degrading conflict" that had emerged between gulls and people at the time of his writing (and in the American context that is the subject of his book) could ultimately leave the Herring Gull as standing for a symbol "for something far less noble [than the bald eagle] in [America's] national character". ${ }^{145}$ The point is the same: what do we reveal of ourselves when we enter such conflicts? To extend this point further, and to put it in the terms of our case of the gulls: what does the attempt to marginalise urban gulls tell us about ourselves?

My suggestion in this article has been that the case of the regulation of seagulls tells us three things. There has firstly been - and there is ongoing - a tightening of a narrative around control in relation to urban gulls. This is expressed in the measures that we have seen in this paper and in the rhetoric around 'we the public against the seagulls' and the notion of the need to take back 'our communities' from the gulls. There is, of course, something vitally interesting about the employment of this rhetoric in the current climate. Is it not notable, for example, that on the one same day in the House of Commons there was a debate about 'gull wars' in one room and about Brexit in another? ${ }^{146}$ And is it not striking - albeit perhaps unsurprising - that in some quarters, EU policies have been (wrongly) implicated in the 'seagull problem', such that Brexit is highlighted as a potential solution ${ }^{147}$ What, then, might be the role played by the purportedly common plight against seagulls in the construction of local identities and indeed national identities? What might be the role of local authority fights against urban gulls in the constitution of local governmental authority? I pose these questions only because when we twin the first point of my paper - the point

\footnotetext{
${ }^{144}$ J. Berger, 'Why Look at Animals?' (1977) in About Looking (2009 [1980]), 24-28.

${ }^{145}$ F. Graham, Gulls: A Social History (1975), 169.

$146<$ https://publications.parliament.uk/pa/cm201617/cmagenda/ob170207.htm > .

147 E.g., The Daily Star, 'Brexit will help Britain fight back against vicious seagulls' (9 February 2017)

$<$ https://www.dailystar.co.uk/news/latest-news/586835/Brexit-help-Britain-fight-vicious-seagulls-EU-

protection $>$.
} 
about the tightening of narratives of control around urban gulls - with the literature on control, we tend to realise that narratives of $i d e n t i t y$ are typically grounded, at some level, in the language of control. ${ }^{148}$

So that is the first point, the emphasis on control. The second point is about the nature of the regulation here. Two broad categories of gull-related measures have been adopted at the local level: measures to control and manage urban gulls and measures to regulate people in the name of regulating gulls. Underpinning these sets of measures are, I have argued, two visions of 'bad behaviour': a vision of the 'bad behaviour' of the gulls (and in which 'natural' behaviour is deemed antithetical to the urban environment and is therefore cast out from that environment) and a vision in which the act of bird-feeding by humans is constructed as being an act of 'bad' and even antisocial behaviour. The regulatory structure that is established in this way (and the conception of 'bad behaviour' that underpins and justifies its formation) involves, in turn, not only a sidelining of the relationship between humans and gulls (and a sidelining of questions about our responsibilities in relation to gulls) but also - and this brings us to the third point of this article the construction of a particular vision of 'public space'. This vision involves the intertwining of ideas of protection (the language of public health and safety and risk), civility (the language of 'good neighbourliness' and of what 'social' behaviour consists in), and responsibility (in which individuals who feed the birds are blamed for broader problems and experiences of insecurity). The regulation of seagulls - and the underlying regulation of people - is oriented towards realising this form of public space and, as I have argued, towards eliminating encounters and confrontations with gulls that disrupt it. But in that transition - a move from the idea of public space as a space of encounter and possibility to a notion of public space as space that is to be free of insecurity the idea of public space disappears.

The story of the regulation of the urban gull in the UK emerges, therefore, as being as much about the socio-legal construction of the 'seagull' that underpins and justifies the regulatory framework recounted in this article as about the construction of public space and about how we understand public space. More broadly, it challenges us to think about where we choose to look when we look for law. The analysis of the multiple "legalities" and "regulatory ensembles" presented in this article ${ }^{149}$ serves as a reminder of the value in looking in the spaces where there are no statutory duties and where local authorities choose how to use their resources. In these spaces - which are places of law just like any other - regulatory forms flourish and produce each

${ }^{148}$ E.g., H. C. White, Identity and Control: How Social Formations Emerge (2008, $2^{\text {nd }}$ edn.), ch.1.

${ }^{149}$ I. Braverman, Wild Life: The Institution of Nature (2015), 229, 153. 
other, and particular conceptions - as of the 'seagull' and the act of 'bird-feeding' - are constructed to justify these forms of regulation. The question that we started off with then - the question of 'how do we think about gulls?' - reveals itself to be inseparable from another question: 'how do we think about law?' The popular construction of the 'seagull' can, in other words, tell us a great deal about the everyday life of law. 